\title{
Reduction in caseload after multidrug therapy in an urban leprosy control programme- a retrospective study in Bombay
}

\author{
C R REVANKAR, P L PAWAR, L S BELURKAR, \\ RASHMI R PAI \& R GANAPATI \\ Bombay Leprosy Project, Vidnyan Bhavan, 11 VN Purav Marg, \\ Sion-Chunabhatti, Bombay 400 022, India
}

Accepted for publication 21 September 1990

Summary A fall in the active registered case prevalence rate together with a fall in the active caseload per worker af ter the introduction of multidrug therapy (MDT) is becoming a managerial issue in leprosy control. A retrospective analysis was undertaken to assess the caseload per paramedical worker with ref erence to active cases for treatment (3341), cases for surveillance (2227) and cases for care after cure (165) at the end of December 1989. All these cases were under the care of 24 paramedical workers.

The analysis showed that the caseload per worker was 239 (active cases 139, plus surveillance cases 93 , plus care after cure cases 7), though active registered case prevalence rate declined from $1 \cdot 82 / 1000$ (before starting MDT) to $0 \cdot 79 / 1000$ by the end of December 1989. The case detection rate was $0 \cdot 49 / 1000$ by the end of 1989. So, although the active registered case prevalence rate declines, the worker will have enough to do because of the need for surveillance and the detection of relapses, early neuritis, early disabilities and care af ter cure. Simultaneously, new case detection and treatment must be continued.

All these aspects need to be considered when programme managers are reviewing leprosy control strategy.

\section{Introduction}

The introduction of multidrug therapy (MDT) in leprosy control programmes has resulted in some drastic reductions in active case prevalence rates. This has induced anxiety as well is euphoria among programme managers and funding agencies, especially among voluntary organizations. The fall in the active prevalence rate has resulted in a significant reduction in the active caseload per paramedical worker (PMW). This has become an important managerial issue as programme managers and the funding agencies of vertical programmes prepare their future strategies for leprosy control. The Government of India has proposed that the leprosy services should be integrated into primary health care once the active prevalence rate has fallen below 2 per $1000 .{ }^{1}$ However, it has been observed that the incidence rate falls very slowly. ${ }^{2}$ Askew ${ }^{3}$ has suggested that where there is a declining active caseload, the PMWs could be responsible for deformity 
care and physiotherapy, etc. Noordeen ${ }^{4}$ pointed out that because of the low endemicity resulting from MDT, other problems remain — such as the possible occurrence of relapses and difficulties involved in contacting chronic defaulters and more distant patients and the breakdown of old subclinical infections.

So, while assessing PMWs workload and preparing to integrate with primary health care, leprosy programme managers must keep all these additional factors in mind. A retrospective study was undertaken by the Bombay Leprosy Project to look into these crucial managerial issues.

\section{Materials and methods}

The Bombay Leprosy Project operates a leprosy control programme in $\mathrm{H}$ and $\mathrm{G}$ municipal wards covering a population of 1.8 million (1989 estimate). In addition, the Project also treats patients living outside the control area. Between 1977 and 1989, 13,487 patients were registered, both from within and outside the project area and MDT was introduced in 1982 following the recommendations of WHO. ${ }^{5}$ All these patients were under the care of 24 trained paramedical workers. A retrospective analysis was undertaken to discover the caseload per worker with reference to active cases, patients under surveillance and patients requiring disability care at the end of December 1989.

\section{Observations and discussion}

All active patients were brought under MDT between 1982 and 1989. The rest were assessed as cured with monotherapy and discharged.

From outside the project area 4,552(34\%) (Table 1) patients were registered. In a city like Bombay, many patients prefer to take treatment far from their homes. This creates case-holding problems for leprosy workers who need more time for patient education and follow-up.

Out of 5733 cases in different categories $1323(23 \%)$ had disabilities. In a total of 1323 disabled patients, 536 (16\%) were under treatment and 622(28\%) were under surveillance (Tables 2 and 3). A total of 165 patients had completed surveillance and were released from control and moved to the care-after-cure register. Although patients with Grade I disability are not usually accounted for when presenting disability figures these patients

Table 1. MDT coverage

\begin{tabular}{lccc}
\hline & $\begin{array}{c}\text { Project area } \\
\text { (No. of cases, } \\
\text { MB + PB) }\end{array}$ & $\begin{array}{c}\text { Outside project area } \\
\text { (No. of cases, } \\
\text { MB + PB) }\end{array}$ & Total \\
\hline $\begin{array}{c}\text { Cases registered } \\
(1977-89)\end{array}$ & $8935(66 \%)$ & $4552(34 \%)$ & $13,487^{*}$ \\
$\begin{array}{c}\text { Cases on MDT } \\
(1982-89)\end{array}$ & $4268(58 \%)$ & $3046(42 \%)$ & 7,314 \\
\hline
\end{tabular}

* A total of 6173 cases were on monotherapy bef ore 1982 and were considered inactive and unfit for MDT. 
Table 2. Distribution of leprosy patients (at the end of 1989)

\begin{tabular}{lccc}
\hline $\begin{array}{l}\text { Distribution of } \\
\text { patients }\end{array}$ & $\begin{array}{c}\text { Project area } \\
\text { (No. of cases) }\end{array}$ & $\begin{array}{c}\text { Outside project area } \\
\text { (No. of cases) }\end{array}$ & Total \\
\hline $\begin{array}{l}\text { Active cases under MDT } \\
\text { Cases under surveillance } \\
(\text { Post RFT) }\end{array}$ & $1423(43 \%)$ & $1918(57 \%)$ & $3341(100 \%)$ \\
Cases for care after cure & $1437(65 \%)$ & $790(35 \%)$ & $2227(100 \%)$ \\
\hline Total & $132(80 \%)$ & $33(20 \%)$ & $165(100 \%)$ \\
\hline
\end{tabular}

* RFT, Release from treatment.

Table 3. Distribution of disability cases

\begin{tabular}{|c|c|c|c|c|c|}
\hline & \multirow{2}{*}{$\begin{array}{l}\text { Total no. } \\
\text { of cases }\end{array}$} & \multicolumn{2}{|c|}{$\begin{array}{c}\text { No. of cases } \\
\text { with disability* }\end{array}$} & \multirow{2}{*}{$\begin{array}{l}\text { Total no. of } \\
\text { cases with } \\
\text { disability }\end{array}$} & \multirow{2}{*}{$\begin{array}{c}\text { No. of cases } \\
\text { without } \\
\text { disability }\end{array}$} \\
\hline & & Grade I & Grade II & & \\
\hline Active cases & 3341 & $233(7 \%)$ & $303(9 \%)$ & $536(16 \%)$ & $2805(84 \%)$ \\
\hline Cases for surveillance & 2227 & $332(15 \%)$ & $290(13 \%)$ & $622(28 \%)$ & $1605(72 \%)$ \\
\hline Cases for care after cure & 165 & $86(52 \%)$ & $79(48 \%)$ & $165(100 \%)$ & - \\
\hline Total & 5733 & $651(11 \%)$ & $672(12 \%)$ & $1323(23 \%)$ & $4410(77 \%)$ \\
\hline
\end{tabular}

* Classification of disability grading was done according to revised grading recommended by WHO $(1988)^{6}$.

nevertheless require considerable attention, in addition to the exhibition of MDT, in order to prevent their decline into a Grade II disability. This is an aspect of the PMWs work that tends to be overlooked but is nevertheless both important and time-consuming. In due course, disabled patients under MDT (536 cases) and disabled patients under surveillance (622 cases) would be transferred to the care-after-cure register.

Programme managers tend to consider a fall in the active registered case prevalence rate and a fall in the active caseload as indicating a need to change the strategy for leprosy control. However, as well as treating active cases, the same worker has to follow-up surveillance patients for detecting relapses, late reversal reactions and silent neuritis. As a result, the caseload per worker goes up to 232 (active cases 139, plus cases for surveillance 93). It is questionable whether early silent neuritis, reversal reactions and early disabilities could be detected unless the surveillance examination is done more frequently (especially in the borderline group) than the current recommendation to undertake surveillance once a year. ${ }^{7}$

As one or two physiotherapy technicians cannot take care of 1323 disabled patients satisfactorily, PMWs have to assist the physiotherapy technicians to take care of disabled cases. The disabled caseload after cure was 7 per PMW. The rest of the 1158 disabled cases who are under treatment as well as under surveillance will join the care-after-cure programme gradually.

Unfortunately, little attention is paid to disability care during cure in MDT 
Table 4. Caseload per paramedical worker (at the end of December 1989)

\begin{tabular}{ccccc}
\hline $\begin{array}{l}\text { No. of } \\
\text { PMWs }\end{array}$ & $\begin{array}{c}\text { Active } \\
\text { cases }\end{array}$ & $\begin{array}{c}\text { Cases for } \\
\text { surveillance }\end{array}$ & $\begin{array}{c}\text { Cases for care } \\
\text { after cure }\end{array}$ & Total \\
\hline 24 & 3341 & 2227 & 165 & 5733 \\
1 & 139 & 93 & 7 & $239 *$ \\
\hline
\end{tabular}

* A caseload of 239 per PMW includes 55 (23\%) patients with disability.

programmes. If care during cure is to be practised, 1158 disabled patients, who have not yet entered the care-after-cure register, will need more attention and will add further to the PMWs workload.

The new case detection rate (NCDR) ranged between 0.33 and $0.65 / 1000$ after introducing MDT in 1982. In 1989, it was 0.49/1000 (Table 4). It must be remembered that case detection has to be continued in addition to the above caseload.

From this retrospective analysis, it can be seen that when assessing the PMW workload and designing the future leprosy control strategy in an endemic situation, in addition to an active caseload and a reduction in the active registered case prevalence rate, activities like new case detection, surveillance and disability care are also to be considered. However, as the urban profile may not be representative of the rural profile, a separate study in endemic MDT districts is essential before advocating any parameters.

\section{Acknowledgments}

This article is based on a paper presented at the Maharashtra Leprosy Workers' Conference at Mahabaleshwar, February 1990.

The authors are thankful to Mrs Nutan S. Ghosalkar for her secretarial assistance.

\section{References}

1 Government of India: Report of the Expert Committee on involvement of primary health care in leprosy eradication, 1988.

2 Jesudasan K, Vijayakumaran P, Pannikar VK, Christian M. Impact of MDT on leprosy as measured by selective indicators. Lepr Rev, 1988; 59: 215-23.

3 Askew AD. Managerial implication of multidrug therapy. Editorial. Lepr Rev, 1985; 56: 89-97.

${ }^{4}$ Noordeen SK. Technology for Leprosy Control, Souvenir, XVI Biennial Conference of Indian Association of Leprologists, 1989.

5 WHO. Chemotherapy for Leprosy Control. Technical Report Series 675, WHO: Geneva 1982.

6 WHO. WHO Expert Committee on Leprosy, Technical Report Series 768, WHO: Geneva 1988.

${ }^{7}$ NLEP. Leprosy: Guidelines on multidrug treatment in endemic districts. Published by Leprosy Division, DGHS, Nirman Bhavan, New Delhi, 1989. 


\title{
Réduction dans le nombre des cas par employé comme résultat de la thérapie à drogues multiples dans un programme urbain de contrôle de la lèpre - une étude rétrospectif à Bombay
}

\author{
C R REVANKAR, P L PAWAR, L S BELURKAR, R R PAI ET R GANAPATI
}

Sommaire - Une chute dans le taux de fréquence des cas actifs liée à une chute dans le nombre de cas actifs sous le contrôle de chaque employé depuis l'introduction de la thérapie à drogues multiples (MDT) est en train de devenir un problème administratif dans le contrôle de la lèpre. Une analyse rétrospective a été menée pour évaluer le nombre de cas traités par chaque auxiliaire médical par rapport aux cas actifs pour traitement (3341), cas pour surveillance (2227) et cas pour soin après récupération, à la fin décembre 1989. Tous ces cas étaient sous la responsabilité de 24 auxiliaires médicaux.

L'analyse a montré que le nombre de cas par employé était de 239 (139 cas actifs + 93 cas pour surveillance +7 cas de soin après récupération), bien que le taux de fréquence des cas actifs avait baissé de 1,82/1000 (avant de mettre la MDT en pratique) jusqu'a 0,75/1000 à fin décembre 1989 . Le taux de détection des cas nouveaux était de 0,49/1000 à la fin de 1989. Alors, bien que le taux de fréquence des cas actifs est en baisse, les employés auront suffisament à faire à cause des besoins de surveillance et détection de rechutes, des névrites précoces, des incapacités précoces et des soins après récupération. En même temps, la détection des nouveaux cas et le traitement doivent continuer. Tous ces aspects doivent être tenus en considération par les administrateurs du programme au moment de réviser la stratégie pour le contrôle de la lèpre.

\section{Reducción en el número de casos bajo el control de cada empleado como resultado de la terapia multimedicinal en un programa urbano de control de la lepra - estudio retrospectivo en Bombay}

\author{
C R REVANKAR, P L PAWAR, L S BELURKAR, R R PAI Y R GANAPATI
}

Resumen - Una disminución en el índice registrado de frecuencia de casos activos junto con una disminución en el número de casos activos bajo el control de cada empleado desde la introducción de la terapia de drogas múltiples (MDT) se está convirtiendo en un problema administrativo en el control de la lepra. Se ha llevado a cabo un análisis retrospectivo con el objeto de averiguar el número de casos tratados por cada empleado paramédico con referencia al número de casos activos para tratamiento (3341), casos para observación (2227) y casos para vigilancia post-recuperación completa (165) para fines de diciembre de 1989. Estos casos estaban repartidos entre 24 empleados paramédicos.

El estudio mostró que el número total de casos por empleado era 239 (139 casos activos + 93 casos para observación +7 casos de vigilancia post-recuperación), aunque el índice registrado de frecuencia de casos activos bajó de 1,82/1000 (antes de la introducción de la MDT) a 0,79/1000 a fines de diciembre de 1989. El índice de detección de casos a finales de 1989 era 0,49/1000. O sea que aunque el índice registrado de frecuencia de casos activos esté en descenso, los empleados se mantendrán ocupados con la vigilancia y la detección de recaidas, neuritis temprana, invalidez temprana y la vigilancia post-recuperación completa. Al mismo tiempo, la detección de nuevos casos y el tratamiento deben continuar.

A la hora de revisar el programa de control de la lepra, los encargados deberán de tomar en cuenta todos estos factores. 